\title{
Incredible India
}

'Incredible India', lyder en dragende turistannonce på $\mathrm{BBC}$ og $\mathrm{CNN}$. Og utroligt er Indien som meget mere end turistland, en fremadstormende stormagt, som ikke altid føler sig behandlet som sådan internationalt. Det har Danmark fået at føle, efter at danske domstole har afvist at udlevere den danske våbensmugler Niels Holck.

Sagen er gået i en slem hårdknude og kunne næppe andet. For Indien og Danmark taler om vidt forskellige ting, når det gælder Niels Holck.

Det handler om national sikkerhed for Indien, som mere end de fleste andre lande har været plaget af terrorisme, udefra som indefra. Det er en gåde for indere, at en udlænding, som aldrig har benægtet, at han har støttet ekstremister med våben, ikke skal stå til regnskab for en domstol.

For Danmark handler det ikke så meget om Holcks forbrydelse. Det er faktisk som om Indien er den skyldige med de dårlige forhold $\mathrm{i}$ fængslerne og brug af tortur for at aftvinge tilståelser. Man kan næppe finde en løsning på denne dansk-indiske sag ved, at Danmark sætter Indien på anklagebænken. Endnu værre er den udbredte opfattelse, at Indien står i taknemmelighedsgæld for dansk ulandsbistand, som bør tilbagebetales med eftergivenhed $\mathrm{i}$ Holck-sagen.
Der var håb om en løsning, hvis begge parter behandlede sagen, som det den er, en forbrydelse begået på indisk territorium af en dansker, der bør stå til ansvar. Det er en ren tilståelsessag, om end Niels Holck har søgt at pakke den ind som hjælp til Indiens undertrykte. Den har en dansk offentlighed med fokus på Indiens fortrædeligheder slugt.

Der er begået alle de fejl, som begås kan fra dansk side. Både statsadvokaten og justitsministeren afviste at gå til Højesteret, da danske domstole kendte, at Holck ikke kunne udleveres på grund af fare for tortur. Indien gav solide garantier for, at han ikke ville blive dødsdømt, ikke underlagt tortur, få særbehandling i fængslet og hurtig tilbageleveret til afsoning af en forventet dom i Danmark. Men så kom al snakken $\mathrm{om}$, at man ikke kan stole på garantier fra Indien. Pinagtigt og ydmygende.

Blandt katastrofale danske fejl var et tilbud om at sende et hold jurister til Indien for at forklare, hvordan det danske retssamfund fungerer. Ikke underligt at Indien sagde nej tak til det nedladende forslag, der lader formode, at sagen bare er, at Indien ikke forstår, hvordan et ægte demokrati fungerer.

\section{Redaktionen}

